
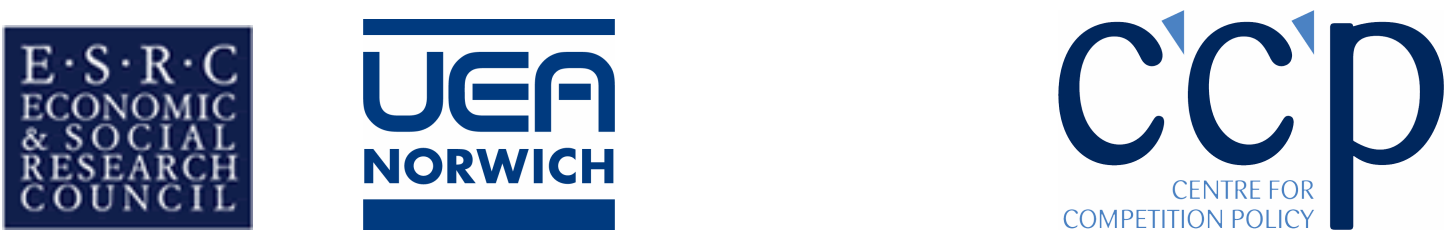

\title{
National Champions and the Two-Thirds Rule in EC Merger Control
}

\author{
by \\ Andrew Scott \\ ESRC Centre for Competition Policy \& The Norwich Law School, \\ University of East Anglia
}

\section{CCP Working Paper 06-6}

\begin{abstract}
The 'two-thirds rule' stands as a caveat to the quantitative jurisdictional thresholds stipulated in the Merger Regulations. It prevents the attribution of a 'Community dimension' to large business mergers where two-thirds of the parties' respective turnovers are made in one and the same member state. It sees the relevant national authority and not the European Commission enjoy competence to assess the competitive effects of such a transaction. In the immediate aftermath of Gas Natural/Endesa - a case which the European Commission accepted only reluctantly did not possess a Community dimension - the Competition Commissioner mooted the legislative repeal of the two-thirds rule. The reception by member states of a proposal on these lines is unlikely to be uniformly generous. This note first reviews the origins and content of the two-thirds rule, before proceeding to consider the current momentum behind and prospects for successful reform. It suggests that a wider rapprochement between divergent perspectives on the best approach to achieving economic development both within and across the member states of the EC - and in particular on the problematic issue of support for 'national champions' - will likely be necessary before any revision can occur.
\end{abstract}

April 2006

JEL Classification: K21

Keywords: EC Law, Mergers, Jurisdiction, Industrial Policy, National Champions

Acknowledgements:

The support of the Economic and Social Research Council (UK) is gratefully acknowledged.

Contact details:

a.d.scott@uea.ac.uk, ESRC Centre for Competition Policy, University of East Anglia, Norwich, NR4 7TJ, UK. www.ccp.uea.ac.uk t: +44 (0) 1603593715 f: + 44(0) 1603 591622

ISSN 1745-9648 


\section{Introduction}

In November 2005, the European Commission confirmed that a proposed merger between two Spanish energy companies - Gas Natural and Endesa - did not possess a 'Community dimension' and should therefore be assessed by the Spanish national competition authority. ${ }^{1}$ This decision was, in itself, somewhat mundane. Its ramifications for the jurisdictional rules stipulated in Article 1 of the EC Merger Regulation, however, may prove to be hugely more significant. ${ }^{2}$ The immediate response of the Competition Commissioner was to moot the legislative repeal of the 'two-thirds rule' that tempers the attribution of a Community dimension to some large business mergers. ${ }^{3}$ The reception by Member States of any such proposal is unlikely to be uniformly generous. This note first reviews the origins and content of the twothirds rule, before proceeding to consider the current momentum behind and prospects for successful reform. It suggests that a wider rapprochement between divergent perspectives on the best approach to achieving economic development both within and across the member states of the EC - and in particular on the problematic issue of support for 'national champions' - will likely be necessary before any revision can occur.

\section{The Origins and Content of the Two-Thirds Rule}

The introduction of the EC merger regime in 1990 was intended to ensure coverage of mergers that would cause 'significant structural changes the impact of which... [went] beyond the national borders of any one Member State'. The question as to when a merger would be best considered at the national, and when the supranational, tier of governance - as determined by the jurisdictional criteria - was originally one of the most fraught in European merger control. Indeed, it was the last matter to be agreed

\footnotetext{
${ }^{1}$ Case COMP/M.3986 Gas Natural / Endesa (C(2005) 4468, 15 November 2005).

${ }^{2}$ Regulation 139/2004/EC on the control of concentrations between undertakings (2004) OJ L24/1 (hereinafter 'Merger Regulation' or 'ECMR'). The 2004 regulation replaced the original merger regulation which was legislated in 1989, and which came into force in 1990.

${ }^{3}$ SEC (2005) 1518/1. For this reason, the Gas Natural / Endesa merger was identified in one survey as the single most important competition development in 2005 - see Cavendish J, "Matter and Team of the Year" (2006) Global Competition Review, 9(1), 18-23.

${ }^{4}$ Recital 8 ECMR.
} 
when the Merger Regulation was first negotiated. ${ }^{5}$ Article 1 of the original Merger Regulation stipulated a test based on combinations of worldwide and Community levels of turnover. ${ }^{6}$ Should this test be satisfied, the given concentration would be deemed to possess a Community dimension, and therefore to be subject to the Commission's exclusive jurisdiction. Should the thresholds not be met, the transaction would fall to be considered only by relevant national authorities. Importantly, this threshold test was circumscribed by the two-thirds rule. This provided that where 'each of the undertakings concerned achieve[d] more than two-thirds of its aggregate Community-wide turnover within one and the same Member State', no Community dimension would arise. The two-thirds rule represents a 'centre of gravity approach' to the division of competence. ${ }^{7}$ It was designed to identify concentrations which involved large companies with interests in more than one country, but which were nonetheless essentially domestic to one Member State. Such cases would be left to the national authority. ${ }^{8}$ As originally conceived by the Commission, this rule would have required three-quarters of turnover to be made in one and the same Member State. The concession was necessary to secure the acquiescence of a number of Member States. 9

After some years' experience, in 1996 the Commission conducted a review of the operation of the jurisdictional thresholds and concluded that they were not operating effectively. ${ }^{10}$ Attention focused, however, not on the allocation of cases per se but on the limited capacity of the system as originally conceived to offer a 'one-stop shop' at

\footnotetext{
${ }^{5}$ Brittan L, "The Law and Policy of Merger Control in the EEC" (1990) European Law Review, 15 , 351-357. It was also unwillingness on the part of Member States to cede sovereignty over large mergers to the Commission that scuppered the first proposal for a merger regulation in 1973 - see Goyder D (2003) EC Competition Law (4 ${ }^{\text {th }}$ edn, Oxford University Press), 337-338.

${ }^{6}$ This test is reflected in Article 1(2) ECMR, and provides that a concentration normally has a Community dimension where (a) the combined aggregate worldwide turnover of all the undertakings concerned is more than $€ 5,000 \mathrm{~m}$, and (b) the aggregate Community-wide turnover of each of at least two of the undertakings concerned is more than $€ 250 \mathrm{~m}$.

${ }^{7}$ Commission, Green Paper on the review of Council Regulation (EEC) No 4064/89, COM(2001) 745 final, para. 23.

${ }^{8}$ There has been some ambiguity in the decisional practice of the Commission as to whether all undertakings concerned in the merger transaction, or just those two or more that generate more than $€ 250 \mathrm{~m}$ (Art. 1(2)ECMR) or €100m (Art. 1(3)ECMR) in aggregate Community-wide turnover. It would seem that the Commission has resolved this issue in favour of the former interpretation - see Broberg M (2003) The European Commission's Jurisdiction to Scrutinise Mergers $\left(2^{\text {nd }}\right.$ ed., The Hague: Kluwer Law International), pp. 26-28. This may allow companies to avoid the two-thirds rule - and so ensure EC level scrutiny) by including an additional undertaking in a given merger transaction that does not meet the two-thirds rule (p. 253).

${ }^{9}$ Goyder, above n.5, p. 340 .

${ }^{10}$ Commission, Green Paper on the Review of the Merger Regulation, COM (1996) 19 final.
} 
which transactions likely to affect a number of national markets could be assessed. This would relieve business of the need to engage with multiple merger control regimes, and avoid the associated regulatory burden that this would impose. The Commission's solution was to introduce a second set of jurisdictional thresholds based on world-wide and Community levels of turnover, but in addition on the levels of turnover generated in each of three or more member states. ${ }^{11}$ Notably, this test was also made subject to the two-thirds rule.

In the most recent review of the Merger Regulation, the focus on refining the one-stop shop principle continued. The primary frustration was that the second set of jurisdictional criteria in force since 1998 had had little positive impact on the allocation of multi-national cases to the Commission. ${ }^{12}$ The recasting of the Merger Regulation saw a move towards greater reliance on enhanced case referral mechanisms on the basis that the attempt to devise 'perfect' quantitative rules was futile. ${ }^{13}$ Recital 11 of the recast Merger Regulation explains that the rules governing the referral of cases 'should operate as an effective corrective mechanism in the light of the principle of subsidiarity', and that these rules 'protect the competition interests of the Member States in an adequate manner'. Interestingly, the continuing value of the two-thirds rule was not questioned during the pre-legislative deliberations and was retained as part of the jurisdictional tests. The Commission's review 'brought to light

\footnotetext{
${ }^{11}$ Regulation 1310/97/EC amending Regulation 4064/89/EEC on the control of concentrations between undertakings (1997) OJ L180/1, Article 1(b). This test is reflected in Article 1(3) ECMR, and provides that a concentration will also normally be found where (a) the combined aggregate worldwide turnover of all the undertakings concerned is more than $€ 2,500 \mathrm{~m}$; (b) in each of at least three Member States, the combined aggregate turnover of all the undertakings concerned is more than $€ 100 \mathrm{~m}$; (c) in each of at least three Member States included for the purpose of point (b), the aggregate turnover of each of at least two of the undertakings concerned is more than $€ 25 \mathrm{~m}$, and (d) the aggregate Community-wide turnover of each of at least two of the undertakings concerned is more than $€ 100 \mathrm{~m}$.

${ }^{12}$ The Commission offered the example that in 2000 only 20 cases were notified under Art.1(3) ECMR, leaving 75 cases still notified to three or more national authorities. Moreover, this figure represented only $5 \%$ of all notifications to the Commission in that year - see Commission, Green Paper on the review of Council Regulation EEC No 4064/89, COM(2001) 745 final, para. 24. However, it should be recalled that at the time of the introduction of the second set of criteria, there was no expectation that it would have a more significant impact than this - see Commission (1999) XXVIIIth Report on Competition Policy 1998 (Luxembourg), 63.

${ }^{13}$ Initially, the Commission had proposed an 'effects-based' model of case allocation that would move away from the quantitative thresholds where a merger gave rise to three or more national level notifications. This proposal was ultimately rejected due to the complexity and incongruity of the disparate national notification criteria across the 25 member states - see Commission, Proposal for a Council Regulation on the control of concentrations between undertakings, COM(2002) 711 final, (2003) OJ C20/4, paras. 13-17.
} 
[no] urgent need to modify the level of the two-thirds rule'. ${ }^{14}$ Indeed, the Commission concluded explicitly that the two-thirds rule had functioned effectively, ${ }^{15}$ and noted that the majority of its consultees concurred with this view. ${ }^{16}$ Tellingly, the two-thirds rule was nowhere mentioned explicitly in the report of an investigation into the proposed reforms undertaken by a House of Lords Select Committee. ${ }^{17}$

The quantitative nature of the jurisdictional tests no doubt allows some mergers that have effects that are of Community interest to remain within the jurisdiction of national authorities (and vice versa). Indeed, a number of sectors - including the energy supply market - have been identified in which mergers that are of Community interest - in that they involve significant trans-frontier effects on competition - are nevertheless unlikely to come within the Merger Regulation due to the fragmented structure of the relevant markets. ${ }^{18}$ The bluntness of the quantitative rules, however, must be considered in context. The rules should be seen as 'a necessary concession to the need for a bright-line determinant of jurisdictional competence in a context where speed of assessment is imperative in sustaining business opportunities and confidence'. ${ }^{19}$ The approach adopted by the Commission and Member States to this sometime lack of efficacy has been to provide mechanisms for the reallocation of cases both before and after notification. ${ }^{20}$ The question, however, is whether there is any justification for a specific rule that accords competence to a Member State, when clearly the transaction will have an impact on competition beyond the borders of that state alone.

\footnotetext{
${ }^{14}$ Commission, above n.7, para. 23.

${ }^{15}$ Commission, above n.13, para. 11.

${ }^{16}$ Commission, Green Paper on the Review of Council Regulation (EEC) No4064/89: Summary of the Replies Received, para. 1. These views were professed despite earlier conclusions that certain transactions with clear cross-border effects are excluded from the scope of the Merger Regulation by this criterion, and that a significant proportion (35\%) of the European business community indicated that the rule does not distinguish 'national transactions' in a satisfactory manner - see Commission, Report on the Application of the Merger Regulation Thresholds, COM(2000) 399 final, para 76.

${ }^{17}$ European Select Committee of the House of Lords (2001-02) Thirty-Second Report: The Review of the EC Merger Regulation. HL165.

${ }^{18}$ Navarro et al (2005) Merger Control in the European Union ( $2^{\text {nd }}$ ed, Oxford University Press), para 4.12. See also Commission, Sector Inquiry Under Article 17 Regulation 1/2003 on the Gas and Electricity Markets: Preliminary Report (Brussels, 2006); Green Paper: A European Strategy for Sustainable, Competitive and Secure Energy, COM(2006) 105 final.

${ }^{19}$ Scott A (ed), Encyclopedia of Competition Law (London: Sweet \& Maxwell), para. 1-1014.

${ }^{20}$ For comment on the initial operation of the new referral mechanisms, see Ryan S (2005) 'The Revised System of Case Referral Under the Merger Regulation: Experiences to Date', Competition Policy Newsletter, 3, pp. 38-42.
} 


\section{Momentum for Change: the Commission's Decision in Gas Natural / Endesa}

The Commission's decision in Gas Natural / Endesa concerned its competence to assess the proposed acquisition of one Spanish energy company (Endesa) by another (Gas Natural). The bid had been notified by Gas Natural to the national competition authority on the basis that while the companies were sufficiently large for the transaction to possess a Community dimension, both earned more than two-thirds of their Community-wide turnover in Spain alone. Endesa contended that the submission made by Gas Natural regarding Endesa's turnover was incorrect, that it had not in fact earned two-thirds of its turnover in Spain, and that - in accordance with the two-thirds rule - the proposed acquisition was for the Commission to consider. ${ }^{21}$

Endesa based its contention on two points. First, it considered that the relevant turnover figures were not those published in its audited accounts as used by Gas Natural, but rather alternative totals elaborated on the basis of the new International Financial Reporting Standards (IFRS). Secondly, it argued that a number of adjustments should be made to these IFRS accounts for 2004 in order to comply with the requirements of Article 5 of the Merger Regulation and the Commission Notice on the calculation of turnover. ${ }^{22}$ These adjustments would reduce Endesa's Spanish turnover below the two-thirds level necessary to preclude Commission jurisdiction. Gas Natural contested these submissions, and highlighted a number of counteradjustments that would also be necessary following the logic proposed by Endesa. ${ }^{23}$

The Commission noted that the 'purely quantitative' nature of the thresholds in Article 1 was intended to allow firms a 'simple and objective mechanism that can be

\footnotetext{
${ }^{21}$ Interestingly, there was some attempt to use the case referral mechanisms in Gas Natural / Endesa, although the requests made by the Italian and Portuguese authorities were rejected by the Commission on the basis that it was not better-placed to conduct an assessment - see Commission press release, IP/05/1356, 27October 2005. Pre-notification referral under Article 4(5) ECMR was precluded on the basis that it is possible only where both the parties so request.

${ }^{22}$ Commission Notice on the calculation of turnover under Council Regulation (EEC) No 4064/89 on the control of concentrations between undertakings (1998) OJ C66/25. The adjustments included elimination of revenues of distribution companies representing a 'mere pass-through'; elimination of revenues from gas exchanges involving no economic consideration; reclassification of some captions of the income statement; elimination of State aids to indigenous coal producers; elimination of revenues from charge of external, security and diversification costs; elimination of assets assigned to Endesa; elimination of compensation for extra costs relating to earlier years; recording of additional revenues at Endesa Italia; deduction of discounts taxes and levies, and other minor adjustments - see above n.1, paras. 29-70.

${ }^{23}$ See above n.1, para. 71.
} 
easily handled' in determining whether a given transaction is notifiable under the Merger Regulation. ${ }^{24}$ Therefore, the Commission explained that 'as a general rule [it] will refer to audited or other definitive accounts... in [all] but exceptional circumstances'. ${ }^{25}$ The Commission concluded that Endesa had not provided sufficient evidence to demonstrate the existence of exceptional circumstances to justify the reference to its non-audited IFRS accounts. ${ }^{26}$ Moreover, it was unwilling 'to enter into a general assessment of the merits of different approaches to accounting provided for in Community law or in the laws of the Member States, in particular when audited accounts exist to only one such standard'. ${ }^{27}$ The use of the unaudited IFRS figures would create a 'disparity of treatment' with regard to all other cases in which the Commission had not adopted such an approach. ${ }^{28}$ The Commission also rejected the second point - that regarding adjustments - put forward by Endesa. It concluded that each of the most significant proposed adjustments was unwarranted. It was therefore unnecessary for the Commission to reach any conclusion on a number of subsidiary revisions, or on the counter-adjustments proposed by Gas Natural. ${ }^{29}$ There was clearly no Community dimension to the proposed concentration. ${ }^{30}$

Subsequent to the Commission's decision, and perhaps contrary to expectations, the Spanish competition authority - the Tribunal for the Defence of Competition recommended that the transaction should be blocked. Nevertheless, in early February 2006 the Spanish government passed the merger subject to twenty conditions. Meanwhile, Endesa has pursued a number of legal actions at the national and European levels designed to stall or preclude the takeover. To date, none of these has been successful.

While the Commission's decision was hardly a ground-breaking jurisprudential event, its political ramifications may prove significant indeed. The emasculation of the Commission's competence in Gas Natural / Endesa moved the Competition

\footnotetext{
${ }^{24}$ ibid., para. 18 (citing Commission Notice, above n.22, para.5).

${ }^{25}$ ibid., para. 19 (citing Commission Notice, above n.22, para.26).

${ }^{26}$ ibid., paras. 23 and 28.

${ }^{27}$ ibid., para. 25.

${ }^{28}$ ibid., para. 27.

${ }^{29}$ ibid., paras. 69-70 and 72. Endesa conceded that one of the counter-adjustments should be made.

${ }^{30}$ The Commission concluded that both companies achieved at least $75 \%$ of their Community-wide turnover within Spain - see "Commission Declares Gas Natural/Endesa Deal Outside Competence" (2005) EU Focus, 178, 10
} 
Commissioner promptly to moot the legislative repeal of the two-thirds rule by way of a note to the College of Commissioners. ${ }^{31}$ This note highlighted the sometime arbitrariness in the allocation of cases under the existing jurisdictional rules, and the risk that different authorities may reach disparate results on equivalent cases. The Commissioner explained that this inconsistency is particularly evident in the energy sector where several cases have been considered by the Commission, ${ }^{32}$ while others and arguably some which were likely to have the most substantial impact on energy markets across national boundaries - have been left to national authorities with unexpected results. ${ }^{33}$ Indeed, the instant case stands as a marker of perceived divergence: Endesa approached the Commission specifically because it considered that the supranational authority may be more amenable to its attempt to rebuff its hostile suitor than the Spanish national counterpart. The Commissioner was also able to cite a number of equivalent cases in the financial services sector. ${ }^{34}$ The Commissioner's view was that the two-thirds rule "no longer reflect[s] an optimal allocation of competence between the national and the Community level, and even constitutes in some instances an obstacle to the consistent treatment of cases". 35

The Commissioner sought to explain further how the situation had changed since 1989. She contended that, given the completion of the Internal Market since the original introduction of the Merger Regulation, maintenance of the two thirds rule now risked the creation of firms able to foreclose national markets to competition from other Community member states. ${ }^{36}$ She also noted that where a merger notified to the Commission did in fact have a significant impact on a distinct national market

\footnotetext{
${ }^{31}$ See above n.3; Buck T (2005) 'Kroes Calls For More Power Over Mergers', Financial Times, 16 November.

${ }^{32}$ ibid., para. 6. Cases cited include Case IV/M.931 Neste / IVO (1998) OJ C218/4; Case COMP/M.3440 ENI / EDP / GDP (2005) OJ L302/69; Case COMP/M.3868 Dong / Elsam / Energi E2 (2006) not yet reported, and Case COMP/M.3696 E.ON / MOL C(2005)5593 final.

33 ibid., paras. 4-7. A particular example cited was the merger of E.ON and Ruhrgas in 2003, which was approved by the German minister for economic affairs after prohibition by the Bundeskartellamt. That such room for inconsistency should arise in the energy sector is particularly poignant given the Commission's difficulties in managing a sound liberalisation of markets in this area - see Commission, above n.18.

34 ibid., para 8.

35 ibid., para 9.

${ }^{36}$ ibid., paras 14-15. The focus on foreclosure of markets is unsurprising given that this is the one anticompetitive effect that may not be considered by the home authority, and cannot be prevented by a neighbouring authority. Any concern that one national authority may not allow sufficient weight to the anti-competitive effects of a significant merger on markets outside national borders can be obviated by the mobilisation of neighbouring national merger regimes to protect such markets from harm.
} 
the newly enhanced case-referral rules would allow for the bifurcation of the assessment between the tiers of governance as appropriate. ${ }^{37}$ In consequence she argued, 'proper' national competence would be respected. She considered it no longer necessary to resort to a 'broad-brush' approach such as the two-thirds rule in order to ensure respect for subsidiarity. In sum, the Commissioner concluded that the ongoing need for the two-thirds rule was "questionable", and that following a consultation with stakeholders and member States on the question she hoped to return to the College with a proposal for legislative reform. ${ }^{38}$

\section{Prospects for Reform: the 'National Champions' Problem}

At first glance, the Commission response to Gas Natural / Endesa seems both rational and reasonable. Indeed, that the Commission should wish to revise the case allocation thresholds has long been predicted: "in the longer term... the Commission will resume its pressure for an expansion of its jurisdiction until the point where virtually all major mergers must be notified in Brussels". ${ }^{39}$ Moreover, some commentators have pre-empted the Commission by offering proposals for the replacement of the existing two-thirds rule by an alternative that would require the merged entity to generate a minimum turnover in at least two member states. ${ }^{40}$ It may be that a lessening of the political sensitivity surrounding merger control, given the widely acknowledged success of the Merger Regulation, will mollify Member States in ceding further sovereignty in this area.

The prospects for a successful overhaul of the two-thirds rule, however, are constrained by realpolitik. The Merger Regulation was promulgated principally under powers set out in Article $308 \mathrm{EC}^{41}$ with the consequence that unanimity will be required for a change to be passed. ${ }^{42}$ The history of the ceding of powers to review mergers by Member States to the Commission does not bode well for the current plan.

\footnotetext{
37 ibid., paras 10-13.

${ }^{38}$ ibid., paras 17-19.

${ }^{39}$ Broberg, above n.8, p. 3.

40 ibid., p. 294; Neven D, R Nutall and P Seabright (1993) Merger in Daylight: The Economics and Politics of European Merger Control (London: Centre for Economic Policy Research), p. 237.

${ }^{41}$ Recital 7 ECMR. A subsidiary basis was Article 83 EC.

${ }^{42}$ Recital 9 and Article 1(4)-(5) ECMR do envisage the revision of the jurisdictional criteria by the Council by way of qualified majority, but only after the making of a report by the Commission which is scheduled for submission by 1 July 2009, and only those criteria stipulated in Article 1(3).
} 
The President of the German Bundeskartellamt, for example, has made plain his aversion to further concession noting that "I am very reluctant to make thresholds the focus of discussion on reform as long as the need to further concentrate merger control in Brussels has not been demonstrated". Specifically, he has asserted "the twothirds rule is the most obvious manifestation of the subsidiarity principle in the Merger Regulation thresholds". ${ }^{43}$ This reticence may well be mirrored in other Member States.

The obstacles raised by this general concern with the retention of competence over even large mergers where they particularly affect national markets is exacerbated by a more specific national interest valued by some Member States. The Commissioner left implicit her real concern when highlighting the possibility that national level authorities may sometimes reach results different to those that the Commission would prefer. Underpinning the Commission's proposal was the irritation that should mergers possessing an ostensible Community dimension be left to national authorities, such bodies may act with inappropriate leniency or rigour in order to foster or sustain 'national champion' companies. At its heart, the Commission's concern centres on the propensity of some Member States to use their national merger control regimes to assist such privileged firms in contravention of the general premises of the EC project and the widely acknowledged lessons of economic history. ${ }^{44}$ Its problem is that Member States are unlikely to be willing to cede further control over one lever by which they remain able to give effect to their industrial policy approach. Reform of the two-thirds rule would eradicate an opportunity for such 'misbehaviour'.

The creation of national champions is sometimes seen as the only way for firms based in a particular country to compete in a global market populated by giant competitors. The approach might involve, for example, the making of soft loans, the unwarranted award of significant public procurement contracts, or - importantly - the bending of merger laws to defend or promote national companies. It is considered particularly

\footnotetext{
${ }^{43}$ Böge U, "Dovetailing Cooperation, Dividing Competence: a Member State's View of Merger Control in Europe", IBA, EC Merger Control: Ten Years On (London, 2000), pp. 363-372.

${ }^{44}$ Recital 2 of the Merger Regulation invokes Article 4(1) of the EC Treaty which provides that it is "essential for the further development of the internal market" that "the activities of the Member States and the Community... be conducted in accordance with the principle of an open market economy with free competition".
} 
important in respect of industry sectors that are deemed strategically important. Notably, the approach tends to benefit firms that are already large with wellestablished political connections. The social welfare implications of the decline or failure of such firms can leave it difficult for politicians to resist supportive intervention. Commissioner Kroes has acknowledged that, "in difficult times, it is sometimes appealing to launch ideas about champions and sectoral initiatives". 45

Although by no means alone, ${ }^{46}$ the French government is particularly associated with the mercantilist national champions approach to industrial policy. Indeed, it has issued a list of key industries that it intends to protect from foreign takeovers, while also acting to defend French ownership of companies in a range of other sectors. ${ }^{47}$ This attitude was given effect in two recent instances: the blocking of a merger between the pharmaceutical company Aventis and Switzerland's Novartis and the orchestration of an alternative takeover by French firm Sanofi, and the facilitation of a merger between utility companies Suez and Gaz de France in order to avoid the acquisition of Suez by Italian firm ENEL. ${ }^{48}$ Prime Minister Dominique de Villepin has identified a perceived need for "real economic patriotism", and contended that "when times are hard... it is a question of gathering our strengths... and defending France and things French... it is better to anchor our companies in the national soil". ${ }^{49}$ Interestingly, the industrial policy debate has also recently been returned to the supranational level with calls for the pursuit of a policy of creating 'European champions'. 50

\footnotetext{
${ }^{45}$ Kroes N, "Building a Competitive Europe: Competition Policy and the Relaunch of the Lisbon Strategy”, speech delivered at Bocconi University, Milan, 7 February 2005.

${ }^{46}$ Notably, following a counter-offer for Endesa by German firm E.On, the Spanish government passed emergency laws (Real Decreto-Ley 4/2006 of 24 February 2006) allowing the foreign takeover to be blocked. The European Commission is currently considering whether action should be taken before the Community courts on this account. In 2004, the former German Chancellor attempted to restructure the German banking sector to the benefit of major national firms (see Benoit B and T Major, "Changing the Rules: Schroder Tries to Redraw Germany's Corporate Landscape Amid Fears of Global Competition", Financial Times, 13 May 2004), while the Swedish Prime Minister entered special pleadings on behalf of Volvo in regard of its proposed merger with Scania - see Whish R, Competition Law $\left(5^{\text {th }}\right.$ edn, Butterworths, 2003), p. 847. There have also been calls for the UK to resile from its more open attitude - see MacAlister T and D Gow, "Uneven Playing Field Leaves UK an Open Goal for Takeovers", The Guardian, 7 March 2006; Hutton W, "Ports in a Storm of Nationalist Feeling", The Observer, 5 March 2006.

${ }^{47}$ Wheatcroft P, "Paris Tramples on Brussels Sensibilities", The Times, 1 September 2005.

${ }^{48}$ Surowiecki J, "Foreign Lessons", The Guardian, 18 March 2006.

${ }^{49}$ Wheatcroft, above n.47.

${ }^{50}$ Strauss-Kahn et al, Round Table: Sustainable Project for Europe: Final Report of the Group of Policy Advisors (Brussels, 2004).
} 
From the outset, in its implementation of the EC merger control regime the Commission has rebuffed industrial policy arguments of this nature. ${ }^{51}$ This stance has recently been commended for the EU and Member States alike by both the Competition Commissioner, ${ }^{52}$ and the former Chairman of the UK Competition Commission. ${ }^{53}$ Their shared basic contention is that firms that operate in competitive national markets are more likely to be efficient and thus able to flourish on more competitive global markets than contemporaries that are insulated from competition on home markets. Given this belief, the grant of support to national champions is perceived as pathological. For Professor Geroski, "it is competitive markets that produce such champions, not national governments... national champions are more likely to become national basket cases than national breadwinners". ${ }^{2}$ Ms Kroes concurs that "vigorous competition at home represents the best industrial policy". 55 She explains that "when industrial policy turns towards inwards, when protectionism leads to economic isolation, the consequence is diminished growth, stagnation and lost prosperity". 56 The consensus among other commentators confirms this attitude: "no industrial policy has been more comprehensively discredited than the notion that the best way to achieve competitiveness abroad is to suppress it at home". 57

\section{Conclusion}

The importance of the Gas Natural / Endesa decision lies in the Commission's appreciation of its own impotence in circumstances such as those that the case presented, and the attention that this focused on the two-thirds rule caveat to the Community dimension thresholds. The two-thirds rule is widely considered important for its recognition of continuing national sovereignty over aspects of economic policy.

\footnotetext{
${ }^{51}$ Case IV/M.53 Aerospatiale / Alenia / de Havilland (1991) OJ L334/42; Case COMP/M.1672 Volvo / Scania (2001) OJ L143/74. See generally, Whish, above n.46, pp. 846-847 and 873; Brittan L, "The Early Days of EC Merger Control”, IBA, EC Merger Control: Ten Years On (London, 2000), pp. 1-7, 5.

${ }^{52}$ Kroes N, above n.45.

${ }^{53}$ Geroski, P, "Competition Policy and National Champions", speech delivered to WIFO, Vienna, 8 March 2005.

${ }^{54} \mathrm{He}$ continued, "in the end, a possibly well meaning policy designed to nurture the sunrise sectors of the future ends up propping up the sunset sectors of the past, littering the industrial landscape with dinosaurs whose ability to compete for political patronage turns out to be far superior to their ability to compete in their own markets" - see ibid.

${ }^{55}$ Kroes, above n.45.

${ }^{56}$ ibid.

${ }^{57}$ Kay, J, “Europe Must Not Create National Champions”, Financial Times, 11 January 2005.
} 
More profoundly, some national governments appear to value the rule for the freedom it allows them to use domestic merger laws to groom domestic flag-bearer businesses capable of competing on the international plane. Others - and not least the Competition Commissioner - consider this 'national champions' approach anathema to the essence of the single market concept, which is thought to lie in open competition and the free movement of capital, and not in protectionist state intervention. ${ }^{58}$ Thus, at the heart of the debate likely to ensue is a clash between competing perspectives on the best approach to achieving economic development both within and across the member states of the EC.

There is some recognition, even in France, that economic protectionism is an errant and counter-productive policy. For example, Nicolas Sarkozy - the French finance minister and presidential hopeful - has agreed that it is no longer possible "to maintain the illusory barrage of a so-called model that each day shows itself no longer to work, nor protect anything or anybody". ${ }^{59}$ M. Sarkozy has also contended, however, that "it is not the right of the State to help its industry, it is a duty". ${ }^{60}$ Unless and until the futility of protectionist industrial policy is more widely and deeply appreciated by Europe's political classes, it would seem best to be sanguine regarding the Commissioner's likelihood of success in persuading all Members States of the need to reform the two-thirds rule. Notably, if this deeper dispute is settled in favour of the logic of free movement of capital and open competition then the need for revision of the two-thirds rule dissolves. The national champions approach would be rejected equally at the national and supranational tiers of governance. The two-thirds rule would then lose its political sensitivity, and revert to its benign allotted role of pragmatic determinant of jurisdictional competence.

\footnotetext{
${ }^{58}$ Kroes, above n. 45 .

${ }^{59}$ Cited in Leader, "France Faces the Future" (2006) The Economist, 1 April 2006, 9-10.

${ }^{60}$ Searjeant G, "Britain Should Not Ignore This European Championship", The Times, 21 May 2004.
} 